\title{
The Effect of Organizational Climate and Job Satisfaction on the Formation of OCB in Marketing Staff of PT. AJMI Pontianak Branch
}

\author{
${ }^{1}$ Sunardi Ginting \\ ${ }^{1}$ Lecturer at Widya Dharma University, Pontianak, Indonesia \\ Received: November 10, 2021 \\ Revised: December 12, 2021 \\ Accepted: December 28, 2021
}

\begin{abstract}
This research was conducted in Pontianak, involving marketing employees at PT. AJMI Pontianak Branch. Respondents of this research consisted of 35 men and 84 women with an age range between 24 s.d. 62 years old, with take home pay based on commission from their sales. This research data processing uses Multivariate Statistical Method, Structural Equation Modeling (SEM), WarpPLS6 Approach. Research findings state that organizational climate is a positive and significant builder for job satisfaction and OCB, job satisfaction is also a positive and significant shaper for OCB and job satisfaction is a significant mediation between organizational climate and OCB in marketing employees of PT AJMI Pontianak Branch.
\end{abstract}

Keywords: Organizational Climate, Job Satisfaction and OCB

\section{Introduction}

Organizational climate is a culture that is created as a result of interactions between members and the organizational system which is reflected in every incident, implementation of policies and daily formal and informal practices (Schneider et al, 2017). Research has proven that individual factors such as the opportunity to contribute something meaningful and organizational recognition, intrinsically challenging work, freedom to excel, positive responses to valuable input from employees are contributors to the formation of a good organizational climate (Bahrami et al, 2016) .

Previous research has clearly defined the measurement dimensions of organizational climate. These dimensions consist of: 1 . Clarity which describes the clarity of the roles of each member of the organization or the clarity of what is expected of them. 2. Standards that describe the measure of how well they should complete their tasks and responsibilities. 3. Responsibility describes the clarity of duties and responsibilities of each member. 4. Flexibility which describes how much opportunity is given to provide ideas and tolerance for differences in implementation with the rules. 5. Rewards that describe the amount of appreciation and recognition for their performance. 6. Team Commitment illustrates the high awareness that they are part and must work together in a team (Permarupan et al., 2013).

Many researches on the influence of organizational climate on the formation of OCB have been carried out. Among these researches, it has been proven that organizational climate has become a positive and significant shaper for OCB (Maamari \& Messarra, 2012; Eskandari \& Ghanbari, 2014).

Job satisfaction can be defined as a pleasant emotional state as a result of an assessment of work or experiences related to it (Locke, 1976). A more specific definition of job satisfaction is a person's general attitude towards his job (Robbins, 2006). From this definition we can distinguish satisfied people tend to view their work positively, while dissatisfied people tend to view their work negatively. This attitude emerges after a person evaluates all the characteristics related to their job. Satisfaction is unique, because it is often not connected to 
rewards from work. Job satisfaction can even be felt when the work someone does is actually beneficial for the company (Rizki, 2019).

Job satisfaction can be measured in terms of cognitive (evaluative), affective (or emotional), and behavioral components. Behavioral symptoms that are often seen in workers who are satisfied with their work include 1 . Having a positive impression of work 2. Conveying positive information about the company to other parties in need 3. Willing to provide assistance to colleagues or other parties in need. 4. Be more obedient to company norms 6. Give more than what is required. However, real measurements must appear directly by involving employees by asking their attitudes on aspects related to their work.

Experts state that a person will experience job satisfaction if he gets a mentally challenging job, appropriate rewards, supportive working conditions, supportive coworkers, work that matches his personality (Robbins, 2006). This research measures satisfaction using the Job Descriptive Index (JDI) (Smith et al., 1969) which measures a person's job satisfaction through five aspects of work such as salary, promotions and promotion opportunities, co-workers, supervision, and the work itself.

Previous research has proven that job satisfaction is a positive and significant shaper for OCB (Gunay, 2018; Subardjo \& Tentama, 2020). Even more specific findings have explained that intrinsic job satisfaction has been shown to be the dominant shaping variable for OCB.

Organ (2014) defines Organizational Citizenship Behavior (OCB) as independent individual behavior that is not directly or explicitly related to the reward system and can improve the effective functioning of the organization. Individual behavior that is free is not bound by rules, but is free in this case in doing work helping other colleagues for the benefit and progress of the company.

Organizational Citizenship Behavior (OCB) is a positive work behavior that is based on personal will and is not influenced by the formal system but affects the overall success of the organization (Moorman, 1991). A person's OCB level describes how far he or she dares to take positive actions that are not explicitly stated in the job description and reward system, but will actually make a positive contribution to their organization (Organ, 1988).

Theoretically it can be said that OCB is a personal commitment shown by a worker without being followed by demands for feedback from service recipients. Workers who have good OCB are generally willing to work beyond the formal responsibilities required of them. Their heroic actions can be seen from their willingness to work according to the rules when there is no supervision, think and act constructively for the progress of their organization, helping colleagues who are having difficulties, their willingness to donate more time and energy when the organization requires extra energy in completing targets without linking it with additional rewards. . Research has proven that

Organ in Shanker (2016) states that the OCB level of workers can be measured through five measurement dimensions consisting of 1 . Conscientiousness or prudence. This precautionary attitude is characterized by timely work behavior, output that exceeds quantity and quality standards and low absenteeism. 2. Altruism or the attitude of prioritizing the interests of other parties. This attitude is characterized by the ability to act spontaneously in providing assistance to coworkers, subordinates or other parties without being associated with. 3. Civic virtues. Ability to develop and manage positive issues for improving organizational conductivity. 4 . Sportsmanship or sportsmanship. This attitude is characterized by the behavior of being able to respond positively to all situations, the ability to find the benefits of every event for the progress of the organization, and easy to accept reality in a positive way. This attitude makes someone's presence a positive impact and problem solving becomes easier. 5. Courtesy or 
manners. This attitude makes a person to be proactive and his behavior that appears to respect others and his ability to appreciate differences.

OCB is indeed a spontaneous behavior of individuals who are free from financial motives or other forms of rewards. However, experts have found that internal elements or encouragement from within, such as the prosocial values held and personal attention to organizational problems, are the main triggers for the emergence of OCB attitudes (Rioux \& Penner, 2001). This behavior arises not because of the encouragement or influence of external factors, but because of the satisfaction that arises internally as a result of successfully doing something different from routine tasks. Research has proven that internal satisfaction with work will encourage someone to do a better job, even trying to help complete work outside of their routine responsibilities Luthans (2006).

\section{Methods}

This research is an extension replication research conducted by re-examining the results of previous studies. The difference lies in the placement of the independent and dependent variables. Whereas previous studies used organizational climate as the independent variable and OCB as the dependent variable, this study uses OCB as the independent variable and organizational climate as the dependent variable. The form of this research is a population study, which takes as many as 119 employees who work as marketing at PT AJMI Pontianak Branch. They consist of 35 men and 84 women. The average age is 43 years, with the youngest age being 24 years and the oldest being 62 years.

\section{Results and Discussion}

\section{Analysis of Validity and Reliability}

\section{Convergent validity of research indicators}

Convergent Validity of Research Indicators describes the ability of a set of research indicators to represent the latent variables. Convergently valid instruments will produce data that represents the concept, so that it can be a good shaper or character for the latent variable. This research uses a loading factor value of 0.50 as a standard one indicator valid convergently (Hair et al, 2010).

To ensure that this research is free from indicators that do not meet the requirements, the researchers conducted a convergent validity test until all of the indicators met the very good standard. The following are the results of loading factors from all research indicators tested using Structural Equation Medeling (SEM) using the WarpPls version 6.0 approach.

Table1. The Value of Loading Factors From All Research Indicators Designed For Marketing Employees of PT AJMI Cab. Pontianak

\begin{tabular}{|c|c|c|c|}
\hline No & Variable & Item & LF \\
\hline \multirow[t]{6}{*}{1} & \multirow{6}{*}{$\begin{array}{l}\text { Climate } \\
\text { Organization } \\
(\mathrm{X})\end{array}$} & $\mathrm{X} 1$ & 0.8 \\
\hline & & $\mathrm{X} 2$ & 0.7 \\
\hline & & $\mathrm{X} 3$ & 0.6 \\
\hline & & $\mathrm{X} 4$ & 0.8 \\
\hline & & $\mathrm{X} 5$ & 0.6 \\
\hline & & X6 & 0.5 \\
\hline \multirow[t]{4}{*}{2} & \multirow{4}{*}{$\begin{array}{l}\text { Job } \\
\text { Satisfaction } \\
\text { (Y1) }\end{array}$} & $Y 1.1$ & 0.8 \\
\hline & & $Y 1.2$ & 0.8 \\
\hline & & Y1.3 & 0.7 \\
\hline & & Y1.4 & 0.7 \\
\hline
\end{tabular}




\begin{tabular}{|l|l|l|l|}
\hline & & $Y 1.5$ & 0.6 \\
\hline 3 & \multirow{3}{*}{ OCB (Y2) } & Y2.1 & 0.8 \\
\cline { 3 - 4 } & & Y2.2 & 0.7 \\
\cline { 3 - 4 } & & Y2.3 & 0.7 \\
\cline { 3 - 4 } & & Y2.4 & 0.9 \\
\cline { 3 - 4 } & & Y2.5 & 0.7 \\
\hline
\end{tabular}

\section{Converging validity and predictive validity of research variables}

One variable is said to have good convergent validity if it has a value of variance extracted > 0.50. In terms of predictive validity, one or a set of exogenous variables is said to have predictive ability or has good relevance to endogenous variables if it has a Q-squared value > 0 . The following details the value of variances extracted Q-squared coefficients for each research variable.

Table2. Avarage Variances Extracted and Q-squared coefficients for Each Research Variable

\begin{tabular}{|l|c|c|c|}
\hline & $\begin{array}{c}\mathrm{X} \\
\text { Climate }\end{array}$ & Y1Kep & Y2OCB \\
\hline Average variances extracted & 0.5 & 0.5 & 0.6 \\
\hline Q-squared coefficients & & 0.480 & 0.442 \\
\hline
\end{tabular}

From Table 2 it can be seen that all of the variables of this study have met the requirements of convergent validity, because they already have a value of variance extracted $>0.05$ and validity because the Q-squared coefficients of all endogenous variables are $>0$.

\section{Discriminant Validity of Research Indicators}

One indicator is said to be discriminantly valid, meaning that it is only effective in collecting data forming one particular latent variable, and is less able to explain other latent variables. Statistically, discriminant validity is measured by the correlation of one indicator with its latent variable which is greater than its correlation with other Latin variables. To see a comparison of the loading factor number with the cross loading of each instrument fed in this study, it can be seen in the following table.

Table 3. Loading Factor and Cross Loading Values For All Research Indicators

\begin{tabular}{|l|r|r|r|}
\hline & $\begin{array}{c}\text { X } \\
\text { Climate }\end{array}$ & Y1Kep & Y2OCB \\
\hline X1 & 0.722 & 0.554 & 0.415 \\
\hline X2 & 0.896 & 0.334 & 0.291 \\
\hline X3 & 0.907 & 0.315 & 0.280 \\
\hline X4 & 0.777 & 0.487 & 0.399 \\
\hline X5 & 0.622 & 0.588 & 0.517 \\
\hline X6 & 0.632 & 0.531 & 0.449 \\
\hline Y1.1 & 0.533 & 0.777 & 0.336 \\
\hline Y1.2 & 0.427 & 0.791 & 0.439 \\
\hline Y1.3 & 0.484 & 0.790 & 0.377 \\
\hline Y1.4 & 0.520 & 0.774 & 0.360 \\
\hline Y1.5 & 0.408 & 0.522 & 0.449 \\
\hline Y2.1 & 0.316 & 0.469 & 0.825 \\
\hline Y2.2 & 0.474 & 0.417 & 0.775 \\
\hline Y2.3 & 0.337 & 0.455 & 0.825 \\
\hline Y2.4 & 0.429 & 0.519 & 0.739 \\
\hline
\end{tabular}

Copyright $@$ 2021, Journal of Asian Multicultural Research for Economy and Management Study, Under the license CC BY-SA 4.0 


\begin{tabular}{|l|l|l|l|}
\hline Y2.5 & 0.473 & 0.504 & 0.723 \\
\hline
\end{tabular}

From Table 3 it can be seen that all items already have a loading factor greater than cross loading with other latent variables, so it is stated that each indicator used in this study already meets the requirements of discriminant validity.

\section{Discrimimum Validity of Research Variables}

Discriminant validity of a set of indicators or questionnaires from one latent variable, measured from the value of Square roots of average variances extracted (AVEs). A questionnaire from one latent variable is said to be valid discriminant if it has a value of Square roots of average variances extracted (AVEs) > its correlation coefficient with other variables. The Square roots of average variances extracted (AVEs) values are the main diagonal figures in the AVEs table and the correlation coefficient. To find out the discriminant validity of the questionnaire, each latent variable can be seen in the following table.

Table 4. Value of Square roots of average variances extracted (AVEs) and Correlation Coefficient

\begin{tabular}{|l|l|l|l|}
\hline & XClimate & Y1Kep & Y2OCB \\
\hline XClimate & 0.674 & 0.650 & 0.527 \\
\hline Y1Kep & 0.650 & 0.708 & 0.617 \\
\hline Y2OCB & 0.527 & 0.617 & 0.772 \\
\hline
\end{tabular}

From Table 4 we can see that the main diagonal figures all have AVEs values that are greater than their correlations with other latent variables. These figures indicate that all of the questionnaires have met the discriminant validity requirements.

\section{Research Indicator Reliability}

This reliability requirement is needed to ensure the consistency of indicators in generating data when it will be used again in the same object condition. For reliability, there are two things that must be taken into account, namely composite reliability and internal consistency reliability. Research indicators are said to meet the requirements of composite reliability if they have Composite reliability coefficients $>0.7$, while the measure of internal consistency that is often used as a benchmark is Cronbach's alpha coefficients which is > 0.6 (Malhorta, 1996). As evidence that all research indicators have met the reliability requirements of both composite reliability and internal consistency, the researcher will display the Composite reliability coefficients values which are all above 0.7 and Cronbach's alpha coefficients values which are also above 0.6. The figures are as in the following table.

Table 5. Composite Reliability Coefficients and Cronbach's Alpha Coefficients

\begin{tabular}{|l|c|c|c|}
\hline & $\mathrm{X}$ & $\mathrm{Y} 1$ & $\mathrm{Y} 2$ \\
\hline Composite reliability coefficients & 0.828 & 0.833 & 0.880 \\
\hline Cronbach's alpha coefficients & 0.748 & 0.749 & 0.829 \\
\hline
\end{tabular}

From table 5, we can see that all the questionnaires used in this study have met the requirements for both composite reliability and good internal consistency of reliability. This is indicated by the value of Composite reliability coefficients which are all above 0.7 and the value of Cronbach's alpha coefficients which is also above 0.6 .

\section{Model Fit and Quality Indices}

A fit model is a model that is feasible and meets the conditions that have been determined by the system. One model fit means that there is a match between the model and the data provided. To meet the fit requirements of 1 model, there are 10 conditions that must be met. The

Copyright $\odot$ 2021, Journal of Asian Multicultural Research for Economy and Management Study, 
following table will detail the results of the fit and quality indices test of this research model which was tested with Structural Equation Modeling (SEM) using the WarpPls version 6.0 approach.

Table 6. Test Results of Fit and Quality Indices Model

\begin{tabular}{|c|c|c|c|c|}
\hline No & Assessment Element & Criteria that must be met & Test Results & Ket Model \\
\hline 1 & $\begin{array}{l}\text { Average path coefficient } \\
\text { (APC) }\end{array}$ & $\begin{array}{c}\text { Fit if } \mathrm{P}<0.05 \text { (Solihin \& } \\
\text { Ratmono, 2013) }\end{array}$ & $0.467, \mathrm{P}<0,001$ & Fit \\
\hline 2 & $\begin{array}{c}\text { Average R-squared } \\
\text { (ARS) }\end{array}$ & $\begin{array}{c}\text { Fit if } \mathrm{P}<0.05 \text { (Solihin \& } \\
\text { Ratmono, 2013) }\end{array}$ & $0.459, \mathrm{P}<0,001$ & Fit \\
\hline 3 & $\begin{array}{c}\text { Average adjusted R- } \\
\text { squared (AARS) }\end{array}$ & $\begin{array}{c}\text { Fit if } \mathrm{P}<0.05 \text { (Solihin } \& \\
\text { Ratmono, 2013) }\end{array}$ & $0.452, \mathrm{P}<0.001$ & Fit \\
\hline 4 & $\begin{array}{l}\text { Average block VIF } \\
\text { (AVIF) }\end{array}$ & $\begin{array}{c}\text { Acceptable if }<=5 \text {, ideally }<= \\
3.3 \text { (Solimun, Fernandes \& } \\
\text { Nurjanah, 2017; Kock, 2012) }\end{array}$ & 1,858 & $\begin{array}{l}\text { Acceptabl } \\
\text { e \& } \\
\text { Ideally } \\
\end{array}$ \\
\hline 5 & $\begin{array}{l}\text { Average full collinearity } \\
\text { VIF (AFVIF) }\end{array}$ & $\begin{array}{c}\text { Acceptable if }<=5 \text {, ideally }<= \\
3.3 \text { (Solimun, Fernandes \& } \\
\text { Nurjanah, 2017; Kock, 2012) }\end{array}$ & 1,871 & $\begin{array}{l}\text { Acceptabl } \\
\text { e \& } \\
\text { Ideally }\end{array}$ \\
\hline 6 & Tenenhaus GoF (GoF) & $\begin{array}{c}\text { small nilainya }>=0,1, \\
\text { medium }>=0,25, \text { large }>= \\
0,36\end{array}$ & 0,487 & Large \\
\hline 7 & $\begin{array}{l}\text { Sympson's paradox ratio } \\
\text { (SPR) }\end{array}$ & $\begin{array}{c}\text { Acceptable if }>=0,7, \text { ideally } \\
=1\end{array}$ & 1,000 & $\begin{array}{l}\text { Acceptabl } \\
\text { e \& } \\
\text { Ideally }\end{array}$ \\
\hline 8 & $\begin{array}{l}\text { R-squared contribution } \\
\quad \text { ratio }(\mathrm{RSCR})\end{array}$ & $\begin{array}{c}\text { Acceptable if }>=0,9 \text {, ideally } \\
=1\end{array}$ & 1,000 & $\begin{array}{l}\text { Acceptabl } \\
\text { e \& } \\
\text { ideally } \\
\end{array}$ \\
\hline 9 & $\begin{array}{c}\text { Statistical suppression } \\
\text { ratio (SSR) }\end{array}$ & Acceptable if $>=0,7$ & 1,000 & $\begin{array}{c}\text { Acceptabl } \\
\mathrm{e}\end{array}$ \\
\hline 10 & $\begin{array}{c}\text { Nonlinear bivariate } \\
\text { causality direction ratio } \\
\text { (NLBCDR) }\end{array}$ & Acceptable if $>=0,7$ & 1,000 & $\begin{array}{c}\text { Acceptabl } \\
\mathrm{e}\end{array}$ \\
\hline
\end{tabular}

Table 6 is the numbers that explain the feasibility and quality of the model iner tested using WarpPls version 6, and all model indicators are declared fit.

\section{Hypothesis Testing}

The study tested 4 hypotheses consisting of 3 direct influence relationships and 12 -stage mediation relationship. The hypothesis of this study is; (1) It is suspected that the better the organizational climate the higher the OCB marketing employees of PT AJMI Cabanga Pontianak; (2) It is suspected that the better the organizational climate the higher the motivation of marketing employees of PT AJMI Cabanga Pontianak; (3) It is suspected that the better the work motivation the higher the OCB marketing employees of PT AJMI Cabanga Pontianak; (4) Allegedly work motivation is mediation between the work climate and OCB marketing employees of PT AJMI Cabanga Pontianak

For hypothesis testing, path coefficient figures are needed from each relationship, both direct and indirect influence relationships. In addition to the path coefficients, $\mathrm{P}$-value data from each path is also needed to determine whether the path coefficient is significant or not. In the following, the researcher will present the direct path coefficients and indirect path coefficients from the relationship variables in this study. 
Table 7. Correlation Coefficient Values and P-values of Each Test Path

\begin{tabular}{|l|l|l|l|c|c|r|l|}
\hline No & H & Line & M 1 & Path & Koef Jalur & \multicolumn{1}{c|}{ P-V } & \multicolumn{1}{|c|}{ Ket } \\
\hline 1 & H1 & X-Y1 & & 1 & 0,691 & $<0.001$ & Highly Significant \\
\hline 2 & H2 & X-Y2 & & 1 & 0,186 & 0,018 & Significant \\
\hline 3 & H3 & Y1-Y2 & & 1 & 0,522 & $<0.001$ & Highly Significant \\
\hline 4 & H4 & X-Y2 & Y1 & 1 & 0,361 & $<0.001$ & Highly Significant \\
\hline
\end{tabular}

From table 7 it can be seen that organizational climate and motivation have a high positive and significant effect on the formation of $\mathrm{OCB}$, organizational climate has a positive and significant influence on the formation of motivation and work motivation is a highly significant mediation between organizational climate and OCB. Based on the path coefficients of each relationship, it can be said that all the hypotheses of this study are accepted.

\section{Research Results Model}

In the following, a complete model is presented that describes the results of testing the direct effect of each exogenous variable on the endogenous variables used in this study.

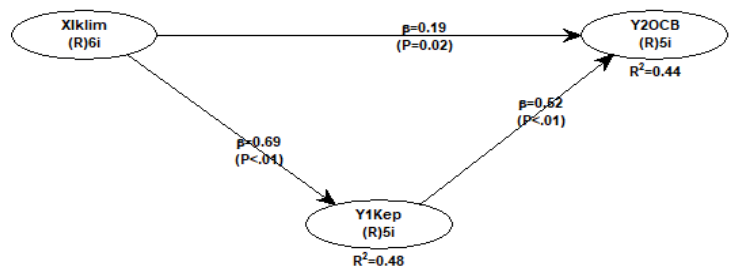

Figure 1. Full Research Results Model

\section{Conclusion}

The results of this study indicate that the organizational climate is a positive and significant shaper for OCB marketing employees of PT AJMI Pontianak Branch. This finding is in line with the results of previous research which stated that organizational climate had a positive and significant effect on OCB 139 workers in the Lebanese commercial banking sector in the Middle East (Maamari \& Messarra, 2012) and 750 employees of Bu-Ali Sina university (Eskandari \& Ghanbari, 2014). . Furthermore, the significant effect of job satisfaction on the formation of OCB is in line with research results which state that job satisfaction has become a positive and significant shaper for OCB employees of the Edirne Finance Office in Turkey (Gunay, 2018) and also for lecturers at University X (Subardjo \& Tentama, 2018). The contribution of each independent variable in forming the dependent variable can be detailed as follows: the direct effect of organizational climate on job satisfaction is 0.69 , the direct effect of work climate on OCB is 0.19 , the direct effect of job satisfaction on OCB is 0.52 and the indirect effect of organizational climate on OCB after mediated job satisfaction is 0.361. All of these influences are positive and significant. From the model, it can be seen that the two independent variables are only able to contribute $44 \%$ of the formation of OCB to marketing employees of PT AJMI Pontianak Branch, and the rest is formed by other factors.

\section{References}

Bahrami, M. A., Barati, O., Ghoroghchian, M. S., Montazer-alfaraj, R., \& Ezzatabadi, M. R. (2016). Role of Organizational Climate in Organizational Commitment: The Case of Teaching Hospitals. Osong public health and research perspectives, 7(2), 96-100.

Eskandari, A., \& Ghanbari, S. (2014). Organizational climate, job motivation and organizational citizenship behavior. International Journal of Management Perspective. 
Locke, E. A. (1976). The nature and causes of job satisfaction. Handbook of industrial and organizational psychology.

Luthans, F., (2006). Organizational Behavior, 7th Ed. Singapore : McGraw-Hill, International Edition

Maamari, B. E., \& Messarra, L. C. (2012). An empirical study of the relationship between organizational climate and organizational citizenship behavior. European Journal of Management, 12(3), 165-174.

Moorman, R. H. (1991). Relationship between organizational justice and organizational citizenship behaviors: Do fairness perceptions influence employee citizenship?. Journal of applied psychology, 76(6), 845.

Organ, D.W. (1988), Organizational Citizenship Behavior: The Good Soldier Syndrome, Lexington Books, Lexington, MA.

Permarupan, P. Y., Saufi, R. A., Kasim, R. S. R., \& Balakrishnan, B. K. (2013). The Impact of Organizational Climate on Employee's Work Passion and Organizational Commitment. Procedia-Social and Behavioral Sciences, 107, 88-95.

Rioux, S. M. \& Penner, L. A. (2001). The Causes of Organizational Citizenship Behavior: A Motivational Analysis. Journal of Applied Psychology, 86, (6): 1306-1314 Robbins, S. P. (2007).

Rizki, J. (2019). Pengaruh Kepuasan Kerja Dan Iklim Organisasi Terhadap Organizational Citizenship Behavior (Studi Pada Karyawan PT. Solo Agung Nusantara Sukoharjo) (Doctoral dissertation, Universitas Ahmad Dahlan).

Robbins, S.P \& Judge T.A. (2015). Perilaku Organisasi. Jakarta: Salemba EmpatSiroos

Schneider, B., González-Romá, V., Ostroff, C., \& West, M. A. (2017). Organizational Climate and Culture: Reflections on the History of the Constructs in JAP

Shanker, M. (2012). Organizational citizenship Behavior: Leveraging effects on Transformational Leaders' Emotional Intelligence. Aweshkar Research Journal, 13(1).

Smith, P. C. (1969). The measurement of satisfaction in work and retirement: A strategy for the study of attitudes.

Subardjo, S., \& Tentama, F. (2020). The role of job satisfaction towards Organizational Citizenship Behavior (OCB). International Journal of Scientific and Technology Research, 9(02), 6089-6091. 